\title{
First Report of the Peanut Stripe Strain of Bean common mosaic virus (BCMV- PSt) Infecting Mungbean in Korea
}

\author{
Hong-Soo Choi ${ }^{1 *}$, Mi-Kyeong Kim', Jin-Woo Park', Su-Heon Lee', Kook-Hyung Kim², Jeong-Soo Kim³, \\ Hassan Karakacha Were ${ }^{4}$, Jang-Kyung Choi ${ }^{5}$ and Yoichi Takanami ${ }^{4}$ \\ 'Department of Plant Pathology, National Institute of Agricultural Science and Technology, Suwon 441-857, Korea \\ ${ }^{2}$ School of Agricultural Biotechnology, Seoul National University, Seoul 151-921, Korea \\ ${ }^{3}$ Division of Horticultural Environment, National Horticultural Research Institute, Suwon 441-440, Korea \\ ${ }^{4}$ Department of Applied Genetics and Pest Management, Faculty of Agriculture, Kyushu University, Fukuoka 812-8581, Japan \\ ${ }^{5}$ Department of Agricultural Biology, Kangwon National University, Chunchon 200-701, Korea \\ (Received on December 15, 2005; Accepted on January 15, 2005)
}

\begin{abstract}
A virus causing chlorotic ringspot, yellow mosaic and vein clearing symptoms was prevalent on mungbean plants around Taean, Korea. The isolate caused mosaic on Chenopodium quinoa, Nicotiana benthamiana, Phaseolus vulgaris and Vicia faba but no symptoms on peanut plants. Inclusion bodies such as scroll, pinwheel and laminated aggregates induced by the virus in the host cells were similar to those produced by members of the Potyvirus subdivision III. Multiple alignment as well as cluster dendrograms of the 709 nucleotide region comprising part of the coat protein gene and 3'untranslated region (UTR) showed that the isolate belongs to the BCMV-PSt subgroup. Altogether, these results support the identification of the causal virus as peanut stripe strain of Bean common mosaic virus (BCMV-PSt).
\end{abstract}

Keywords : Bean common mosaic virus, identification, mungbean, occurrence, seed- transmission

Bean common mosaic virus (BCMV), a type member of the genus Potyvirus, family Potyviridae, has flexuous particles of 847-886 nm in length (Brunt et al., 1996). Several potyviruses infect large-seeded legumes and are economically important because they are transmitted through seed (up to $83 \%$ in Phaseolus vulgaris and $7-22 \%$ in tepary bean) and are spread naturally by aphids in a non-persistent manner (Demski et al., 1984; Morales and Bos, 1998; Xu et al., 1991). The initial and still definitive identification depends on responses of a series of $P$. vulgaris host differential cultivars first described by Drijfhout et al. (1978). The method identified seven pathogroups out of the predicted 16. BCMV has been divided on the basis of serological reactivity into two serogroups, BCMV serogroup A

\footnotetext{
${ }^{*}$ Corresponding author.

Phone) +82-31-290-0401, FAX) +82-31-290-0434

E-mail) hschoi@rda.go.kr
}

and Blackeye cowpea mosaic virus (BlCMV) serotype B (McKern et al., 1992; Khan et al., 1993). The Potyvirus Study Group of the Plant Virus Subcommittee (PVS) of the International Committee on Taxonomy of Viruses (ICTV) examined many properties of the BCMV subgroup including published nucleic acid and amino acid sequences available at the time, and proposed criteria for the taxonomy and classification of viruses and strains within the subgroup (Mink et al., 1994). Items proposed and accepted by ICTV included changing the name of BCMV serotype A strains to Bean common mosaic necrosis virus (BCMNV) while retaining the name for the BCMV serotype B strains (Vetten et al., 1992).

BCMV was first isolated from mungbean (Vigna radiata) in Iran by Kaiser et al. (1968) and was called mungbean mosaic virus even though it was closely related to BCMV. This virus was the most important disease affecting mungbeans in Iran and was was found in most areas where the crop was cultured. Nene (1973) found the virus, which he renamed mosaic mottle, to be widely distributed in northern India. In greenhouse screening trials, he found resistance to the virus in two mungbean lines. Thereafter, Kaiser and Mossahebi (1974) described a seed-transmitted virus disease of mungbean in Iran of which seed transmission rates in 12 mungbean lines ranged from 8 to $32 \%$ and yield reductions from 11 mungbean lines infected through seed, by 31 to $75 \%$. In Thailand, a virus was isolated from mungbean plants showing mosaic symptoms and identified as a strain of BCMV (Tsuchizaki et al., 1989). In Korea the distribution of BCMV is correlated with the widespread occurrence of peanut, kidney bean and adzuki bean crops (Lee, 1981; data not shown). Based on biological, cytopathological and the 3'-untranslated region (UTR) sequence properties, in this study we report the characterization of a $\mathrm{BCMV}$ isolate found to infect mungbean in Korea. 


\section{Materials and Methods}

Sample collection. A survey of mungbean virus disease was carried out in Taean, Chungcheongnam-do, Korea. The survey was conducted by walking through mungbean fields, while inspecting the crops for viral disease symptoms. Disease incidence was calculated as the number of plants showing disease symptoms relative to the total number of plants observed.

Host range studies. To determinate the infectivity of virus isolates and the symptoms induced on test plants, 5-10 plant seedlings of each of the species listed in Table 1 at the 3-5 leaf stage were inoculated by mechanical inoculation with sap extracted in $0.1 \mathrm{M}$ phosphate buffer, $\mathrm{pH}$ 7.0. The plants were put in an insect-free greenhouse maintained at 20$25^{\circ} \mathrm{C}$ with $12-16 \mathrm{~h}$ light period. Disease symptoms were

Table 1. Symptoms on test plants caused by two Korean isolates of Bean common mosaic virus (BCMV) from mungbean and peanut

\begin{tabular}{|c|c|c|}
\hline Indicator plant test & $\begin{array}{l}\text { Mungbean isolate } \\
\text { of } \mathrm{BCMV}\end{array}$ & $\begin{array}{c}\text { Peanut isolate } \\
\text { of BCMV }\end{array}$ \\
\hline Chenopodium amaranticolor & $\mathrm{nl}, \mathrm{cr} /-^{\mathrm{a}}$ & $\ln 1 /-$ \\
\hline C. quinoa & $\mathrm{cl} / \mathrm{cl}, \mathrm{m}$ & $\ln 1 /-$ \\
\hline Nicotiana benthamiana & $\mathrm{cl} / \mathrm{sm}$ & $\mathrm{cl} / \mathrm{sm}, \mathrm{mal}$ \\
\hline N. tabacum cv. 'bright yellow' & $-1-$ & $-1-$ \\
\hline N. tabacum cv. 'X-nc' & $-1-$ & $-1-$ \\
\hline Physalis floridana & $-1-$ & $-1-$ \\
\hline Petunia spp. & $-1-$ & $-1-$ \\
\hline Datura stramonium & $-1-$ & $-1-$ \\
\hline Tetragonia expansa & $-1-$ & $-1-$ \\
\hline Sesamum indicum $\mathrm{L}$. & $-1-$ & $-1-$ \\
\hline Perilla frutescens & $-1-$ & $-1-$ \\
\hline Impatiens balsamina $\mathrm{L}$ & $-1-$ & $-1-$ \\
\hline Zinnia elegans Jacq. & $-1-$ & $-1-$ \\
\hline Cucumis sativus L. & $-1-$ & $-1-$ \\
\hline Citrullus lanatus & $-1-$ & $-1-$ \\
\hline Cucurbita moschata Duch & $-1-$ & $-1-$ \\
\hline Raphanus sativus L. & $-1-$ & $-1-$ \\
\hline Brassica campestris & $-1-$ & $-1-$ \\
\hline Brassica rapa $\mathbf{L}$ & $-1-$ & $-1-$ \\
\hline Chrysanthemum coronarium & $-1-$ & $-1-$ \\
\hline Phaseolus vulgaris L. & $-/ \mathrm{cl}, \mathrm{vc}$ & $\mathrm{nr} / \mathrm{ve}$ \\
\hline Vicia faba & $-/ \mathrm{vc}, \mathrm{m}$ & $\mathrm{nl} /-$ \\
\hline Glycine max Merr. & $-1-$ & $-1-$ \\
\hline Phaseolus radiatus L. & $\mathrm{nl}, \mathrm{vn} / \mathrm{cl}, \mathrm{m}$ & $-1-$ \\
\hline Vigna angulari & $-/ \mathrm{m}$ & $-/ \mathrm{vc}$ \\
\hline V. unguiculata & $-1-$ & $-1-$ \\
\hline
\end{tabular}

${ }^{a}$ symptoms developed on inoculated/upper leaves; $\mathrm{cl}$, chlrorotic local; nl, necrotic local; mm, mild mosaic; m, mosaic; sm, severe mosaic; vc, vein clearing; -, no symptoms. recorded three times a week for 30 days and compared with those of the BCMV-PSt isolate isolated from peanut. Both symptomatic and non-symptomatic plants were verified for virus infection by electron microscopy.

Seed transmission. Hundred seeds of each of the 5 mungbean cultivars obtained from National Crop Experiment Station (NCES) and Jeonnam Agricultural Research \& Extension Services (JARES) were sown in trays of sterilized soil and put in an insect-free greenhouse maintained at $20-25^{\circ} \mathrm{C}$ with $12-15 \mathrm{~h}$ light period. The seedlings were inspected for disease symptoms 30 days after emergence and analyzed for BCMV presence by ELISA.

Indirect-ELISA. Indirect-antibody coated enzyme linked immunosorbent assay (Indirect-ELISA) was conducted essentially as described by Clark and Bar-Joseph (1984) using a mixture monoclonal antibodies (MAb) (Agdia, USA). The MAbs and conjugate were both diluted at 1:200. Except for the MAbs that were incubated for $2 \mathrm{~h}$ at $37^{\circ} \mathrm{C}$, all the other incubations were carried out at $37^{\circ} \mathrm{C}$ for $1 \mathrm{~h}$. Quantitative measurements of generated p-nitrophenol were made by determining absorbance at $405 \mathrm{~nm}\left(\mathrm{~A}_{405}\right)$ in a Thermo Max microplate reader 4.0 (Molecular Devices, USA). Twice the mean absorbance readings of non-infected negative control values were used as the positive/negative thresholds.

Electron microscopy (EM). Dip preparations were prepared by grinding a small piece of infected Phaseolus radiatus L. in 2-3 drops of $2 \%$ phosphotungstic acid, $\mathrm{pH} 7.0$. The extract was mounted on a carbon-stabilized, Formvarcoated grid. Two weeks after inoculation, infected leaves were harvested and immediately cut with a sharp blade (which was washed with $75 \%$ alcohol after every cut) into $1-3 \mathrm{~mm}$ thick pieces. Ultrathin sections were conducted as described by Choi et al. (1993). For interpretation of results, the sections were viewed under electron microscope LEO $912 \mathrm{AB}$ (Carl Zeiss, Germany) at $80 \mathrm{kV}$.

RT-PCR, cloning, and sequencing. Total RNA was extracted from infected leaf samples essentially as described by Prescott and Martin (1987). In order to ascertain the taxonomic status of the isolate, $3^{\prime}$ terminal region consisting of part of the coat protein (CP) gene and 3'-untranslated region (UTR) of the virus isolate was amplified following the RT-PCR procedure described by Pappu et al. (1993). PCR products were analyzed on $0.8 \%$ agarose gels and DNA band of interest purified using GFXTM PCR DNA band and Gel Band Purification Kit (Amersham Pharmacia Biotech., Piscataway, USA). The amplified PCR products were cloned in pGEM-T vector (Promega) and sequenced. 
BCMV sequences obtained were phylogenetically compared to those of other BCMV (GenBank and EMBL) using the multiple sequence alignment application of DNAMAN version 4.0 (Lynnon Biosoft, Quebec, Canada) full optimal sequence alignments and neighbor-joining method options of Saitou and Nei (1987) with 1000 bootstrap (Felstein, 1985 ) replications. Percent nucleotide (nt) and ORF amino acid (aa) sequence identities between virus isolates were calculated using the distance between all pairs of sequences in the multiple alignments. CP-UTR sequences used for comparison and their database accession numbers were as follows: U05771 (Peanut stripe virus (PStV)-blotch isolate), Z21700 (PStV-Indonesian blotch isolate), AF200624 (PStV-severe necrotic strain); Y11773 (PStV-Australia T6 isolate), AF063222 (PStV-Ts strain), AJ312438 (BCMV-Y isolate), AJ312437 (BCMV-R isolate), Y17823 (BICMVFlorida isolate), S66253 (BICMV-W isolate), U72204 (Cowpea Moroccan aphid-borne mosaic virus isolate), L21766 (BCMV-NL4 strain), AY112735 (BCMV-NL1 strain), L12740 (BCMV-US1 strain), L19472 (BCMV-NL2 strain), L11890 (BCMV-Mexican strain), AB012663 (AzMV-H strain), U60100 (AzMV-WA strain), U23564 (Dendrobium mosaic virus isolate).

\section{Results and Discussion}

The virus disease incidence on mungbean around Taean, Chungcheongnam-do province of Korea was $10 \%$. The most common symptoms in the field were chlorotic ringspot, yellow mosaic and vein clearing on the youngest leaves (Fig. 1). The virus isolate from mungbean caused systemic mosaic symptoms on Nicotiana benthamiana, $P$. vulgaris and $V$. angulari similar to those induced by the peanut isolate of BCMV. However, the isolate also induced vein clearing and mosaic on Chenopodium quinoa, Vicia faba and $P$. radiatus $\mathrm{L}$. but no reaction on peanut cultivars (Tables 1 and 2). Moreover, the isolate could not infect $N$. tabacum var. Xanthi-nc, Phyalis floridana, Sesamum

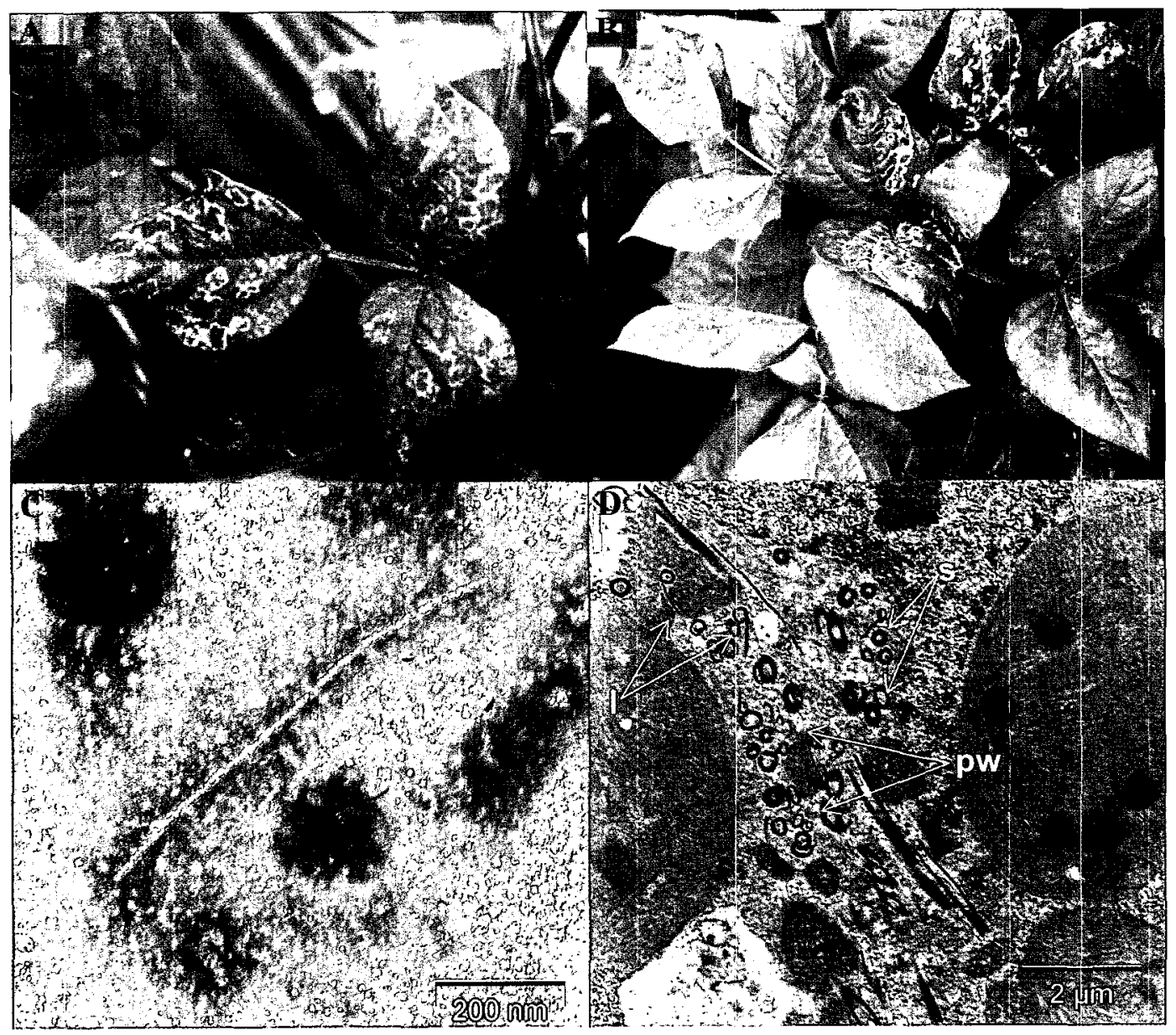

Fig. 1. BCMV-PSt infected mungbean plants showing (A and B) yellow mosaic and vein banding symptoms in the field, (C and D) electron micrograph of virus particles in crude sap and of typical cytoplasmic inclusion bodies like pinwheels, scrolls and laminate aggregates in cells of Phaseolus radiatus, respectively. s, scrolls; 1, laminate aggregates; pw, pinwheels. 
Table 2. Peanut cultivars showing symptoms at viral infection 2 weeks after inoculation with two Korean isolates of BCMV isolated from mungbean and peanut

\begin{tabular}{ccc}
\hline \hline Peanut cultivars & $\begin{array}{c}\text { Mungbean isolate of } \\
\text { BCMV }\end{array}$ & $\begin{array}{c}\text { Peanut isolate of } \\
\text { BCMV }\end{array}$ \\
\hline ShinDaegang & $-/-^{\mathrm{a}}$ & $-/ \mathrm{ym}, \mathrm{vb}$ \\
Wang & $-/-$ & $-/ \mathrm{ym}, \mathrm{vb}$ \\
Aul & $-/-$ & $-/ \mathrm{vb}$ \\
Namdae & $-/-$ & $-/ \mathrm{ym}, \mathrm{vb}$ \\
Daewon & $-/-$ & $-/ \mathrm{ym}, \mathrm{vb}$
\end{tabular}

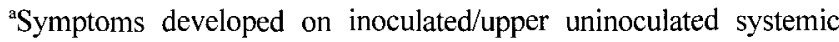
leaves; ym, yellow mosaic; vb, vein banding; -, no symptom.

Table 3. Seed transmission rates of BCMV on different mungbean cultivars

\begin{tabular}{cccc}
\hline \hline \multirow{2}{*}{ Cultivar } & \multicolumn{2}{c}{ No. of Plants } & Infection rates \\
\cline { 2 - 3 } & Investigated & Infected & $(\%)$ \\
\hline Gyeongseon & 100 & 1 & 1.0 \\
Geumseong & 100 & 2 & 2.0 \\
Samgang & 100 & 2 & 1.9 \\
Aul & 100 & 4 & 4.6 \\
Soseon & 100 & 5 & 4.9 \\
\hline Total & 500 & 15 & 2.9 \\
\hline
\end{tabular}

indicum, Datura stramonium, V. unguculata and Glycine max, similar to peanut isolate of BCMV (Table 1).

All five mungbean cultivars tested were shown to transmit BCMV by seeds with transmission rate ranging from 1.0 to $4.9 \%$. The highest seed transmission rate $(4.9 \%)$ was observed in mungbean cultivar Soseon, while Gyeongseon had the lowest with $1 \%$ seed transmission rate (Table 3). EM examination of crude sap extracts revealed flexuous rod-shaped particles with an average length of 760 $\mathrm{nm}$. Mungbean isolate induced typical cytoplasmic cylindrical inclusion bodies like pinwheels, scrolls and laminated aggregates in cells of $P$. radiatus $\mathrm{L}$. similar to peanut isolate of BCMV (Fig. 1).

The isolate's 3'-UTR sequenced was found to contain 709 nucleotides (nts) comprising $453 \mathrm{nt} \mathrm{CP}$ and $256 \mathrm{nt}$ UTR with a poly (A) tail. Homology analysis of CP/UTR sequences split the strains into 4 groups, i.e., PStV, BICMV, BCMV/AzMV and DeMV groups (Fig. 2). A detailed analysis of the aligned 3'-UTR nucleotide sequences revealed a varying degree of sequence identity with isolates the mungbean isolate and Korean-peanut isolate sharing 100\% nt, whereas only $91 \%$ identity with isolate Dendrobium mosaic virus (DeMV). Moreover, when compared to other strains, this isolate shared $>95 \%$ nt sequences with $\mathrm{PStV}$ isolates, $<95 \%$ with BCMV, BICMV/AzMV.

Based on biological, phenotypical and molecular proper-

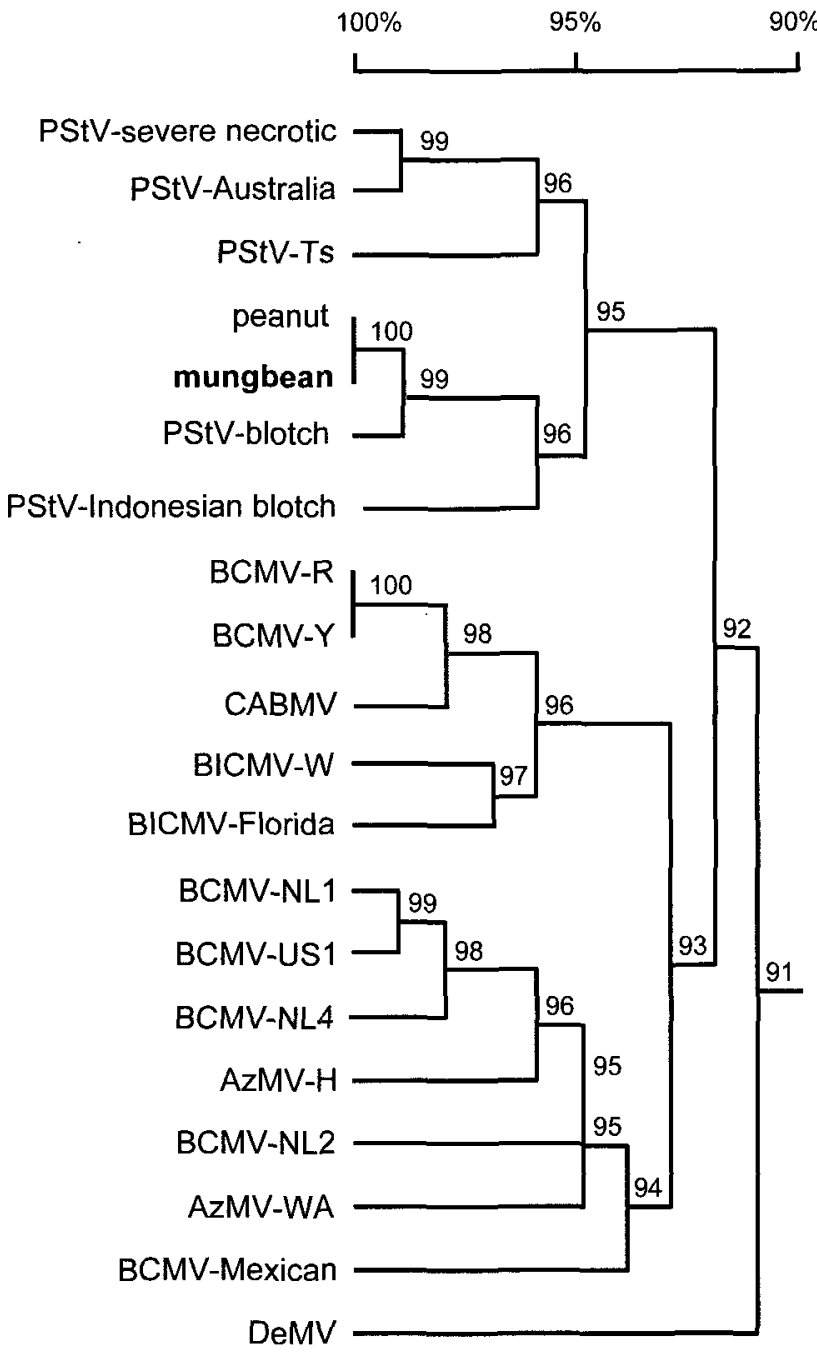

Fig. 2. Phylogenetic tree derived from nucleotide sequence alignments of mungbean CP/ UTR fragments and those of other 18 BCMV strains.

ties we have characterized the strain of BCMV infecting mungbean in Korea. Biological studies showed that the isolate could not infect peanut plants despite the fact that symptoms on the host were similar to those induced by the mungbean isolate, implying that biological variation exists between the two isolates. This finding complements that of Wongkaew and Dollet (1990) who found biological variation of PStV to be high. When crude saps as well as thin sections were observed under an electron microscope, filamentous particles and inclusion bodies similar to those induced by members of a Potyviridae family in infected host cells were observed. This strongly suggested that this virus belongs to the Potyvirus group.

Furthermore, tests with antisera raised against particles of BCMV detected the isolate, indicating that the isolate is a strain of BCMV. Phylogenetic analyses of this isolate clustered the mungbean isolate within the PStV group 
indicating that the mungbean isolate was highly similar to that of peanut. This clustering of mungbean isolate with the PStV isolates from other countries strongly implied that PStV strains and/or isolates have a common ancestry. This closeness of PStV-peanut with PStV-mungbean possibly suggests that the later isolate arose not long ago enough for significant divergent to occur.

In a previous paper (Choi et al., 2001), BCMV-PSt was found to infect peanut around Suwon, Gyeonggi-do province of Korea. Serology and molecular analyses clearly identified it to be a strain of BCMV. This study has found the similar strain infecting mungbean around Taean, Chungcheongnam-do province. Until now, PStV was a strain known to infect in several other legumes including Arachis hypogaea, Lupinus albus, Glycine max and Sesamum spp. (Brunt et al., 1996). When and how the virus changed its host is not clear. Interestingly the BCMV-PSt isolated from mungbean could not infect peanuts despite repeated tests. This probably may be due to the alteration of the gene responsible for infectivity or that the peanut cultivar in question was resistant to the isolate, whichever may be the case needs further investigation.

\section{Acknowledgements}

We are sincerely grateful to Mr. J. S. Lee for assistance with the electron microscopic work. This research was supported in part by a grant from the BioGreen 21 Program, Rural Development Administration.

\section{References}

Brunt, A. A., Crabtree, K., Dallwitz, M. J., Gibbs, A. J., Watson, L. and Zurcher, E. J. 1996. Plant Viruses Online: Descriptions and Lists from the VIDE Database. Version: 20th August 1996. 'URL http://biology.anu.edu.au/Groups/MES/vide/'.

Choi, H. S., Kim, J. S., Lee, K. H. and Shim, J. S. 1993. Ultrastructure and virus replication in cells of rice plant infected with RBSDV. RDA J. Agric. Sci. 35:344-353.

Choi, H. S., Kim, J. S., Cheon, J. U., Choi, J. K., Pappu, S. S. and Pappu, H. R. 2001. First Report of Peanut Stripe Virus (Family Potyviridae) in South Korea. Plant Dis. 85:2313.

Clark, M. F. and Bar-Joseph, M. 1984. Enzyme immunosorbent assays in plant virology. Methods Virol. 7:51-85.

Demski, J. W., Reddy, D. V. R., Sowell, Jr. G. and Bays, D. 1984. Peanut stripe virus -a new seed-borne potyvirus from China infecting groundnut (Arachis hypogaea). Ann. Appl. Biol. 105:495-501.

Drijfhout, E., Silbernagel, M. J. and Burke, D. W. 1978. The identification of two new strains of bean common mosaic virus.
Netl. J. Plant Pathol. 84:13.

Felsenstein, J. 1985. Confidence limits on phylogenies: An approach using the bootstrap. Evolution 39:783-791.

Kaiser, W. J., Danesh, D., Okhovat, M. and Mossahebi, H. 1968. Diseases of pulse crops (edible legumes) in Iran. Plant Dis. Rptr 52:687-691.

Kaiser, W. J. and Mossahebi, H. 1974. Natural infection of mungbean by Bean common mosaic virus. Phytopathology 64:1209-1214.

Khan, J. A., Lohuis, D., Goldbach, R. and Dijkstra, J. 1993. Sequence data to settle the taxonomic position of BCMV and BICMV strains. J. Gen. Virol. 74:2243-2249.

Lee, S. H. 1981. Studies on virus disease occurring in various crops in Korea. Res. Rep. RDA 23:62-74.

McKern, N. M., Shukla, D. D., Barnett, O. W., Vetten, H. J., Dijkstra, J., Whittaker, L. A. and Ward, C. W. 1992. Coat protein properties suggest that azuki bean mosaic virus, blackeye cowpea mosaic virus, peanut stripe virus and three strains from soybean are all strains of the same potyvirus. Intervirology 33:121-134.

Mink, G I., Vetten, J., Ward, C. W., Berger, P. H., Morales, F., Myers, J. R., Silbernagel, M. J. and Barnett, O. W. 1994. Taxonomy and classification of legume-infecting potyviruses: a proposal from the Potyviridae Study Group of the Plant Virus Subcommittee of ICTV. Arch. Virol. 139:231-235.

Morales, F. J. and Bos, L. 1988. CMI/AAB Description of Plant Viruses No. 337.

Pappu, S. S., Brand, A., Pappu, H. R., Rybicki, E. P., Gough, K. H., Frankel, M. J. and Niblett, C. L. 1993. A polymerase chain reaction method adopted for selective amplification and cloning of 3'-sequences of potyviral genomes: application to dasheen mosaic virus. J. Virol. Methods 41:9-20.

Prescott, A. and Martin, C. 1987. A rapid method for the quantitive assessment of levels of specific mRNAs in plants. Plant Mol. Biol. Rptr. 4:219-224.

Saitou, N. and Nei, M. 1987. The neighbor-joining method: a new method for reconstruction of phylogenetic trees. Mol. Biol. Evol. 4:406-425.

Tsuchizaki, T., Iwaki, M., Thongmeearkom, P., Sarindu, N. and Deema, N. 1989. Bean common mosaic virus isolated from mungbean (Vigna radiata) in Tailand. Tech. Bull. Trop. Agricul. Res. Center 21:150-157.

Vetten, H. J., Lesemann, D. E. and Maiss, E. 1992. Serotype A and $\mathrm{B}$ strains of BCMV are two distinct potyviruses. In: Barnett OW (ed) Potyvirus taxonomy. Springer, Wien NewYork, pp. 415-431 (Archives of Virology [Suppl] 5) PStV-Thai coat protein gene variability 1667 .

Wongkaew, S. and Dollet, M. 1990. Comparison of peanut stripe virus strains using symptomatology on particular hosts and serology. Oleagineux 45:267-278.

$\mathrm{Xu}, \mathrm{Z}$., Chen, K., Zhang, Z. and Chen, J. 1991. Seed transmission of peanut stripe virus in peanut. Plant Dis 75:723-726. 